\title{
PENINGKATAN KEMAMPUAN MENYAJIKAN TEKS BERITA MELALUI PEMBELAJARAN KUANTUM PADA SISWA KELAS VIII-6 MTS NEGERI 5 JAKARTA TAHUN 2019
}

\author{
Sri Hartati \\ MTs Negeri 5 Jakarta \\ Email: srihartatibakti@gmail.com \\ https://doi.org/10.36052/andragogi.v7i2.95 \\ Diterima: 9 Oktober 2019 | Disetujui: 2 Desember 2019 | Dipublikasikan: 30 Desember 2019
}

\begin{abstract}
Abstrak
Penelitian ini bertujuan untuk mengungkapkan peningkatan aktivitas belajar siswa dan kemampuan menyajikan data dan informasi dalam bentuk teks siswa kelas VIII-6 MTs Negeri 5 Jakarta tahun 2019 melalui pembelajaran kuantum. Penelitian ini merupakan penelitian tindakan kelas yang terdiri atas dua siklus. Tiap siklus terdiri atas tahap perencanaan, tindakan, observasi, dan refleksi. Berdasarkan hasil analisis data pada prasiklus, siklus I dan siklus II diketahui adanya peningkatan nilai rata-rata yang diperoleh siswa dalam pembelajaran menulis teks berita. Pada prasiklus diperoleh nilai rata-rata sebesar 60,20, pada siklus I sebesar 66,94 dan pada siklus II nilai rata-rata siswa sebesar 78,7. Peningkatan keterampilan menulis teks berita diikuti dengan perubahan perilaku siswa ke arah yang positif, yaitu siswa semakin aktif dan antusias saat mengikuti pembelajaran menulis teks berita melalui pembelajaran kuantum.
\end{abstract}

Kata Kunci: keterampilan menulis teks berita, aktivitas belajar, pembelajaran kuantum

\begin{abstract}
This research aims to determine the increase in student learning activities and the increase in student ability to present data and information in the form of news text in VIII-6 classroom of MTs Negeri 5 Jakarta through quantum learning. This research is a classroom action research and consisting of two cycles. Each cycle consists of planning, action, observation and reflection. Based on the results of data analysis in pre-cycle, cycle I and cycle II, it is know that there is an increase in the average value obtained by students in news text writing skills. In pre-cycle, the average value is 60.20, in the first cycle 66.94 and in the second cycle the average value of students is 78.7. The improvement was followed by changes in student behavior in a positive direction; students are increasingly active and enthusiastic when learning to write news texts through quantum learning.
\end{abstract}

Keywords: news test writing skill level, learning activities, quantum learning 


\section{PENDAHULUAN}

B erita adalah sebuah laporan atau pemberitahuan mengenai terjadinya sebuah peristiwa atau keadaan yang bersifat umum dan baru saja terjadi yang disampaikan oleh wartawan di media massa (Djuraid, 2009: 50). Berita merupakan fakta objektif. Sebagai fakta yang objektif berita harus bebas dari pendapat pribadi manapun termasuk dari jurnalis maupun editor. Berita adalah laporan tentang fakta secara apa adanya dan tidak dibuat-buat kebenarannya. Berita memiliki keterbatasan ruang, maka dari itu harus disampaikan secara efektif.

Berita merupakan hal yang sudah hampir dapat dipastikan setiap orang konsumsi setiap hari. Baik itu berita dalam media cetak maupun media elektronik. Terutama dengan adanya kemajuan teknologi, berita sudah dengan mudahnya diakses oleh siapa saja dan dimana saja. Begitu pun dengan pembuatannya, dengan adanya kemudahan teknologi, sebagian besar masyarakat dapat menjadi pembuat berita meskipun hanya sebatas berita dalam broadcast massage dalam media sosial.

Teks berita pun menjadi penting dipelajari di sekolah. Dengan dipelajarinya teks berita di sekolah, akan meningkatkan keterampilan siswa dalam menganalisis dan memilah informasi yang ada menjadi sebuah bentuk teks berita dengan baik dan benar. Tidak hanya itu, dengan terbiasa dalam menganalisis dan menyimpulkan berita maka siswa diharapkan dapat memilah informasi yang didapatkan dalam seluruh aspek kehidupannya, tidak hanya pada berita. Selain itu, kemampuan siswa dalam mengolah informasi dan menerjemahkannya ke dalam susunan kata-katanya sendiri pun dapat meningkatkan keterampilan siswa dalam menulis.

Di dalam Kurikulum 2013, teks berita merupakan salah satu kompetensi dasar yang harus dikuasai siswa jenjang sekolah menengah pertama kelas VIII. Kompetensi dasar tersebut tercantum dalam Permendikbud nomor 23 tahun 2016. Teks berita sendiri merupakan menempati 2 kompetensi dasar pengetahuan dan 2 kompetensi dasar keterampilan. Penelitian ini berfokus pada keterampilan dasar 4.2 yaitu menyajikan data dan informasi dalam bentuk berita secara lisan dan tulis dengan memperhatikan struktur, kebahasaan, atau aspek lisan (lafal, intonasi, mimik, dan kinesik).

mempelajari teks berita dalam kehidupan siswa, guru berperan penting dalam proses pembelajaran agar siswa dapat meningkatkan keterampilan menulis teks berita. Guru dituntut mampu menerapkan model pembelajaran yang tepat. Namun, pada kenyataannya guru seringkali hanya memakai metode ceramah.

Kurangnya variasi dalam
pembelajaran memicu rendahnya
kemampuan menyajikan teks berita. Hal
tersebut dapat diketahui dari hasil
penilaian teks berita yang diikuti oleh
34 siswa di kelas VIII-6. Dari 34 siswa di
kelas VIII-VI, hanya 2,94\% atau 1 siswa
yang berhasil mencapai nilai KKM yaitu
75 , sedangkan $97,06 \%$ atau 33 siswa
belum mencapai nilai KKM.

Tidak hanya berpengaruh terhadap keterampilan menulis teks berita, variasi dalam pembelajaran juga 
berpengaruh terhadap aktivitas belajar siswa. Hamalik (2009: 93) menyatakan bahwa aktivitas belajar merupakan kegiatan yang dilakukan oleh siswa dalam kegiatan pembelajaran. Aktivitas belajar merupakan kegiatan atau tindakan baik fisik maupun mental yang dilakukan oleh individu untuk membangun pengetahuan dan ketrampilan diri dalam kegiatan pembelajaran. Aktivitas belajar akan menjadikan pembelajaran efektif. Guru tidak hanya menyampaikan pengetahuan dan keterampilan saja. Namun, guru harus mampu membawa siswa untuk aktif dalam belajar.

Dengan mengetahui pentingnya model pembelajaran, maka peneliti memberikan solusi untuk menerapkan pembelajaran kuantum pada topik teks berita. Menurut Wena (2013:160) pembelajaran kuantum merupakan cara baru yang memudahkan proses belajar, yang memadukan unsur seni dan pencapaian terarah untuk segala mata pelajaran dengan menggabungkan keistimewaan-keistimewaan belajar menuju bentuk perencanaan pengajaran yang akan melejitkan prestasi siswa. Pembelajaran kuantum bermakna interaksi-interaksi yang mengubah energi menjadi cahaya. Dengan kata lain, pembelajaran kuantum mengubah kemampuan dan bakat alamiah siswa menjadi cahaya yang akan bermanfaat bagi diri sendiri dan orang lain.

Menurut DePorter (2005: 7-8) pembelajaran kuantum memiliki lima prinsip yang mempengaruhi seluruh aspek pembelajaran kuantum. Prinsipprinsip pembelajaran kuantum meliputi (1) segalanya berbicara; (2) segalanya bertujuan; (3) pengalaman sebelum pemberian nama; (4) akui setiap usaha; dan (5) jika layak dipelajari, maka layak pula dirayakan.

Pembelajaran kuantum mampu menciptakan suasana belajar yang menyenangkan sehingga mampu menciptakan ketenangan psikologi siswa, memiliki kepercayaan diri ikut serta aktif dalam pembelajaran, dan proses belajar siswa lebih terarah pada materi yang sedang dipelajari karena dikaitkan dengan pengalamanpengalaman siswa. Namun, pembelajaran kuantum menuntut profesionalisme yang tinggi dari seorang guru, memerlukan modal dan fasilitas yang cukup banyak, serta menuntut penguasaan kelas yang baik.

Langkah-langkah pembelajaran kuantum dikenal dengan singkatan TANDUR yang merupakan kepanjangan dari tumbuhkan, alami, namai, demonstrasikan, ulangi dan rayakan. Unsur-unsur tersebut membentuk basis struktural keseluruhan yang melandasi pembelajaran kuantum (DePorter, 2005: 9). Dengan pembelajaran kuantum ini diharapkan dapat meningkatkan motivasi untuk para siswa dalam menyajikan teks berita dan meningkatkan hasil belajar siswa kelas VIII-6.

Penelitian ini bertujuan untuk mengungkapkan peningkatan aktivitas belajar siswa dan kemampuan menyajikan data dan informasi dalam bentuk teks siswa kelas VIII-6 MTs Negeri 5 Jakarta tahun 2019 melalui pembelajaran kuantum.

\section{METODE PENELITIAN}

Model penelitian tindakan yang akan digunakan dalam PTK ini adalah model Kemmis McTaggart. Model tersebut dipilih karena langkahnya 
sederhana dan tepat untuk penelitian tindakan kelas.

Pada model tersebut satu siklus terdiri dari 4 kegiatan yaitu perencanaan (planning), pelaksanaan (acting), pengamatan (observing), dan refleksi (reflecting).

Perencanaan merupakan tahapan awal yang harus dilakukan guru sebelum melakukan sesuatu. Diharapkan rencana tersebut berpandangan ke depan, serta fleksibel untuk menerima efek-efek yang tak terduga dan dengan rencana tersebut secara dini kita dapat mengatasi masalah.

Pelaksanaan (acting) merupakan penerapan dari perencanaan yang telah dibuat yang dapat berupa suatu penerapan model pembelajaran tertentu dengan tujuan untuk memperbaiki atau menyempurnakan model yang sedang dijalankan.

Pengamatan berfungsi untuk melihat dan mendokumentasikan pengaruh-pengaruh yang diakibatkan oleh tindakan dalam kelas. Hasil pengamatan ini merupakan dasar dilakukannya refleksi sehingga pengamatan yang dilakukan harus dapat menceritakan keadaan yang sesungguhnya.

Refleksi di sini meliputi kegiatan analisis, sintesis, penafsiran (penginterpretasian), menjelaskan, dan menyimpulkan. Hasil dari refleksi adalah diadakannya revisi terhadap perencanaan yang telah dilaksanakan, yang akan digunakan untuk memperbaiki kinerja guru pada pertemuan selanjutnya.

Penelitian tindakan ini mengkaji proses dan dampak penerapan model pembelajaran kuantum terhadap keterampilan menulis teks berita. Adapun variabel yang akan diteliti yaitu keterampilan menyusun informasi dan data dalam bentuk teks berita, perubahan aktivitas belajar peserta didik, serta prosedur yang tepat dalam menerapkan pembelajaran kuantum

Subjek penelitian tindakan kelas (PTK) adalah siswa kelas VIII-VI Tahun Pelajaran 2019-2020, dengan jumlah keseluruhan 34 siswa yang terdiri dari 18 siswa perempuan dan 16 siswa lakilaki.

Metode pengumpulan data yang akan digunakan dalam penelitian ini adalah:

1. Jurnal

Jurnal merupakan catatan yang dibuat oleh guru maupun siswa. Jurnal yang dibuat pada siklus I dan siklus || ini ada dua macam, yaitu lembar jurnal siswa dan lembar jurnal guru.

Jurnal siswa yang diberikan terdiri atas lima pertanyaan dan diisi secara individu. Lima pertanyaan itu meliputi : (1) pendapat siswa tentang pembelajaran menulis teks berita melalui pembelajaran kuantum; (2) pendapat siswa tentang kesulitan yang dialami pada saat menulis teks berita; (3) pendapat siswa tentang gaya mengajar yang dilakukan oleh guru; (4) pendapat siswa tentang manfaat yang diperoleh setelah mengikuti pembelajaran kuantum; (5) pesan dan saran siswa terhadap pemanfaatan media pembelajaran menulis teks berita.

Jurnal guru merupakan hasil pengamatan peneliti mengenai 
uraian kejadian selama mengikuti pelajaran. Aspek-aspek pengamatan yang terdapat dalam jurnal guru antara lain: (1) kesiapan siswa dalam mengikuti pembelajaran; (2) keaktifan siswa selama proses pembelajaran menulis teks berita melalui pembelajaran kuantum; (3) perilaku siswa selama kegiatan menulis teks berita; (4) tanggapan siswa terhadap pemanfaatan media pembelajaran; (5) catatan yang berisi kejadian-kejadian yang muncul pada saat pembelajaran menulis teks berita melalui pembelajaran kuantum.

\section{Wawancara}

Wawancara dilakukan terhadap siswa yang nilai tesnya tinggi, sedang, dan rendah. Wawancara digunakan untuk mengetahui minat siswa terhadap pembelajaran menulis teks berita, untuk mengetahui permasalahan dan kesulitan yang dialami siswa dalam menulis teks berita, tanggapan mengenai metode dan teknik yang digunakan, dan manfaat pembelajaran menulis teks berita menggunakan pembelajaran kuantum.

\section{Dokumentasi Foto}

Dokumentasi diambil pada saat pembelajaran berlangsung sebagai bukti fisik kegiatan pembelajaran. Dokumentasi yang digunakan pada penelitian ini adalah dokumentasi berupa foto. Dalam pengambilan foto pada penelitian ini, peneliti dibantu seorang teman dengan kondisi peneliti dan siswa dalam keadaan yang sewajarnya atau tidak dibuat- buat. Hal tersebut dilakukan agar pengambilan foto dapat berjalan dengan baik.

\section{Observasi}

Observasi digunakan untuk mengamati sikap siswa selama proses pembelajaran menulis teks berita menggunakan pembelajaran kuantum. Hal-hal yang diamati dalam observasi yaitu: 1) kesiapan siswa dalam mengikuti pembelajaran; 2) perhatian dan sikap siswa pada saat mendapat penjelasan dari guru; 3) siswa senang dan tertarik terhadap media pembelajaran; 4) siswa bersungguhsungguh dalam menulis teks berita; 5) siswa aktif bertanya kepada guru, dan 6) siswa tidak mengganggu temannya.

\section{Tes Evaluasi}

Tes dilakukan sebanyak dua kali yaitu pada siklus I dan siklus II. Tes digunakan untuk mengetahui pengetahuan dan keterampilan siswa tentang menulis teks berita setelah mengikuti proses pembelajaran. Skor penilaian berdasarkan aspek-aspek yang sudah ditentukan. Ada enam aspek pokok yang dijadikan kriteria penilaian, yaitu : (1) kelengkapan unsur berita (mengandung ADIKSIMBA); (2) keruntutan pemaparan (isi urut dan jelas sehingga mudah dipahami); (3) penggunaan kalimat (singkat dan jelas); (4) penggunaan kosakata (tepat); (5) kemenarikan judul; dan (6) ketepatan penggunaan ejaan dalam berita.

Data variabel kedua dan ketiga adalah data kualitiatif yang akan diolah 
menggunakan teknik perbandingan tetap melalui prosedur seperti yang diungkapkan oleh Moleong (Suryadi \& Berdiati, 2018: 247) berikut.
a. Reduksi data
b. Kategorisasi
c. Sintesisasi
d. Menyusun hipotesis kerja

Pemilihan teknik perbandingan tetap dilakukan atas pertimbangan bahwa data diperoleh melalui beberapa siklus dan untuk melihat perubahan antarsiklus akan dilihat dari hasil perbandingan data satu siklus dengan siklus lainnya.

Data variabel pertama yaitu adalah skor hasil pengukuran menggunakan tes berbentuk angka kuantitatif. Data ini akan diolah menggunakan statistik deskriptif kecenderungan memusat yaitu ratarata, mean, median, dan modus. Data hasil olahan setiap siklus akan dibandingkan dengan hasil olahan siklus lainnya dan disajikan dalam bentuk grafik sehingga dapat melihat pola perubahannya.

\section{TEMUAN DAN PEMBAHASAN}

\section{Temuan}

a. Prasiklus

Sebelum melakukan penelitian tindakan kelas, peneliti telah mendapatkan hasil tes keterampilan menulis teks berita dengan metode pembelajaran konvensional. Hasil tes prasiklus ini berfungsi untuk mengetahui seberapa besar keterampilan awal siswa dalam menulis teks berita. Hasil keterampilan menulis teks berita prasiklus dapat dilihat pada tabel dibawah ini.
Tabel 1 Hasil Keterampilan Prasiklus

\begin{tabular}{cccc}
\hline No & $\begin{array}{c}\text { Rentang } \\
\text { Nilai }\end{array}$ & Frekuensi & $\begin{array}{c}\text { Presentase } \\
(\%)\end{array}$ \\
\hline 1 & $85-100$ & 0 & 0 \\
2 & $75-84$ & 1 & 2,94 \\
3 & $60-74$ & 20 & 55,88 \\
4 & $50-59$ & 12 & 35,29 \\
5 & $0-49$ & 1 & 2,94 \\
\hline
\end{tabular}

Data pada Tabel 1 tersebut menunjukkan bahwa keterampilan siswa dalam menulis teks berita masih dalam kategori cukup dan masih jauh dari kriteria ketuntasan minimal yang telah ditetapkan dalam penelitian ini, yaitu sebesar 75, sehingga perlu ditingkatkan. Data ini menjadi dasar untuk dilakukan perbaikan dengan melaksanakan pembelajaran menulis teks berita dengan pembelajaran kuantum.

b. Siklus I

Pembelajaran menulis teks berita pada siklus I ini merupakan pemberlakuan tindakan awal penelitian dengan menggunakan pembelajaran kuantum. Tindakan pada siklus ini dilaksanakan dengan tujuan untuk memperbaiki keterampilan siswa dalam menulis teks berita dan memecahkan masalah siswa yang muncul dalam keterampilan menulis teks berita. Hasil pelaksanaan pembelajaran menulis teks berita dengan pembelajaran kuantum pada siklus I terdiri atas data tes dan nontes dengan hasil penelitian sebagai berikut.

1) Data tes

Hasil tes keterampilan menulis teks berita dengan pembelajaran kuantum dapat dilihat pada tabel di bawah ini. 
Tabel 2 Hasil Keterampilan Siklus 1

\begin{tabular}{cccc}
\hline No & $\begin{array}{c}\text { Rentang } \\
\text { Nilai }\end{array}$ & Frekuensi & $\begin{array}{c}\text { Presentase } \\
(\%)\end{array}$ \\
\hline 1 & $85-100$ & 1 & 2,94 \\
2 & $75-84$ & 12 & 35,29 \\
3 & $60-74$ & 12 & 35,29 \\
4 & $50-59$ & 8 & 23,52 \\
5 & $0-49$ & 1 & 2,94 \\
\hline
\end{tabular}

Tabel menunjukkan bahwa hasil tes keterampilan menulis teks berita siswa memiliki rata-rata 66,94 dalam kategori cukup.

2) Data non tes

Hasil observasi siklus I dapat dilihat pada tabel di bawah ini.

Tabel 3 Aktivitas Siswa Siklus 1

\begin{tabular}{clc}
\hline No & \multicolumn{1}{c}{ Aspek Observasi } & Presentase \\
\hline 1 & $\begin{array}{l}\text { Kesiapan siswa dalam } \\
\text { pembelajaran } \\
\text { Siswa memperhatikan } \\
2\end{array}$ & 61,76 \\
penjelasan yang \\
disampaikan oleh guru \\
Siswa senang dan \\
tertarik dengan media \\
pembelajaran \\
yang digunakan \\
$\quad \begin{array}{l}\text { Siswa bersungguh- } \\
\text { sungguh dalam menulis } \\
\text { teks berita }\end{array}$ \\
$\begin{array}{l}\text { Siswa aktif bertanya } \\
\text { kepada teman maupun } \\
\text { guru apabila } \\
\text { menemukan kesulitan } \\
\text { Siswa tidak } \\
\text { mengganggu temannya }\end{array}$ \\
\hline
\end{tabular}

\section{3) Refleksi}

Berdasarkan hasil tes siklus I menunjukan bahwa keterampilan menulis teks berita dalam kategori baik, 13 siswa atau 38,23\% sudah mencapai nilai batas tuntas. Hasil tersebut menunjukkan bahwa keterampilan menulis teks berita pada siswa kelas VIII-6 perlu ditingkatkan karena nilai ini belum memenuhi kriteria keberhasilan, yaitu $75 \%$.

Berdasarkan hasil observasi, jurnal, wawancara, dan dokumentasi foto diperoleh hasil perubahan perilaku siswa dalam pembelajaran menulis teks berita tergolong cukup baik. Dalam pembelajaran siswa merasa lebih mudah untuk memahami materi menulis teks berita. Meskipun demikian, beberapa siswa masih terlihat kurang bersemangat dan kurang antusias dalam mengikuti pembelajaran. Hal tersebut disebabkan kurang tertariknya siswa terhadap materi yang diberikan guru.

\section{c. Siklus II}

Pada siklus II peneliti kembali memberikan pembelajaran menulis teks berita dengan pembelajaran kuantum dengan melakukan perbaikan untuk mengatasi masalah yang ada pada siklus I. Penjabaran hasil tes dan nontes keterampilan menulis teks berita pada siklus II dapat dilihat berikut ini.

\section{1) Data tes}

Hasil tes keterampilan menulis teks berita melalui pembelajaran kuantum dapat dilihat pada tabel di bawah ini.

Tabel 4 Hasil Keterampilan Siklus 2

\begin{tabular}{cccc}
\hline No & $\begin{array}{c}\text { Rentang } \\
\text { Nilai }\end{array}$ & Frekuensi & $\begin{array}{c}\text { Presentase } \\
(\%)\end{array}$ \\
\hline 1 & $85-100$ & 11 & 32,35 \\
2 & $75-84$ & 16 & 47,06 \\
3 & $60-69$ & 7 & 20,59 \\
4 & $50-59$ & 0 & 0 \\
5 & $0-49$ & 0 & 0 \\
\hline
\end{tabular}


Pada tabel hasil tes keterampilan menulis teks berita siklus II dapat dilihat bahwa keterampilan siswa dalam menulis teks berita telah mengalami peningkatan, dengan nilai rata-rata 78,79 dengan kategori baik.

2) Data nontes

Berikut adalah penjabaran hasil observasi terhadap perilaku siswa.

Tabel 5 Aktivitas Siswa Siklus 2

\begin{tabular}{clc}
\hline No & Aspek Observasi & Presentase \\
\hline 1 & $\begin{array}{l}\text { Kesiapan siswa dalam } \\
\text { pembelajaran }\end{array}$ & 100 \\
2 & $\begin{array}{l}\text { Siswa memperhatikan } \\
\text { penjelasan yang } \\
\text { disampaikan oleh guru }\end{array}$ & 88,23 \\
3 & $\begin{array}{l}\text { Siswa senang dan tertarik } \\
\text { dengan media }\end{array}$ & 94,12 \\
& $\begin{array}{l}\text { pembelajaran yang } \\
\text { digunakan }\end{array}$ \\
4 & $\begin{array}{l}\text { Siswa bersungguh- } \\
\text { sungguh dalam menulis } \\
\text { teks berita }\end{array}$ \\
5 & $\begin{array}{l}\text { Siswa aktif bertanya } \\
\text { kepada teman maupun } \\
\text { guru apabila menemukan } \\
\text { kesulitan }\end{array}$ \\
\hline 6 & $\begin{array}{l}\text { Siswa tidak mengganggu } \\
\text { temannya }\end{array}$ & 98,82 \\
\hline
\end{tabular}

\section{3) Refleksi}

Hasil tes menulis teks berita melalui pembelajaran kuantum pada siklus II telah mencapai nilai batas ketuntasan, yaitu nilai rata-rata siswa adalah 79,41 . Nilai rata-rata ini telah menunjukkan bahwa kemampuan siswa dalam menulis teks berita termasuk dalam kategori baik. Hal ini disebabkan oleh pemahaman siswa dalam menulis teks berita jauh lebih mendalam dibandingkan sebelumnya.
Pada siklus II ini, sebanyak 11 siswa memperoleh nilai dengan kategori sangat baik, 16 siswa dengan kategori baik, 7 siswa dengan kategori cukup, dan tidak ada siswa yang memperoleh nilai dengan kategori kurang dan sangat kurang. Hasil belajar siswa telah memperlihatkan adanya peningkatan.

Peningkatan nilai siswa dalam menulis teks berita melalui pembelajaran kuantum pada siklus II juga diiringi dengan adanya perubahan tingkah laku siswa ke arah positif. Dari hasil yang diperoleh pada kegiatan pembelajaran menulis teks berita siklus II, didukung oleh suasana kelas yang lebih kondusif, siswa lebih antusias dan bersemangat ketika menulis teks berita. Dari hasil jurnal yang diisi pada akhir pembelajaran menyatakan bahwa ada perubahan positif yang dialami oleh siswa. Terlihat dari jawaban siswa yang merasa senang dan tertarik dengan pembelajaran menulis teks berita. Siswa merasa lebih mudah menulis teks berita dengan adanya media yang disajikan oleh guru.

Ketika dilakukan wawancara, siswa menyatakan tidak mengalami kesulitan karena materi yang diberikan guru dapat dipahami dengan lebih jelas, siswa merasa senang karena pembelajaran menulis teks berita tidak membosankan. Hal ini membuktikan adanya perubahan positif yang dialami siswa dalam kegiatan pembelajaran menulis teks berita pada siklus II.

Dapat disimpulkan bahwa pembelajaran yang dilakukan pada siklus II dapat dinyatakan berhasil 
serta mengalami peningkatan. Menurut hasil penelitian, masih terdapat kelemahan dalam proses pembelajaran yaitu masih terdapat siswa yang malu untuk bertanya kepada guru mengenai materi yang belum dipahami.

\section{Pembahasan}

Dalam pembahasan ini perlu dikemukakan penelitian relevan atau penelitian dengan variabel sejenis yang telah ditulis sebelumnya. Adapun Penelitian Tindakan Kelas (PTK) yang relevan pertama ditulis Rizka Fitri Amalia dengan judul "Peningkatan Keterampilan Menulis Teks Berita Menggunakan Model Pembelajaran Quantum Teaching dan Teknik 3M pada Siswa Kelas VIII B SMP Negeri 1 Keling Jepara." Penelitian Tindakan Kelas ini dilakukan dalam dua tahap, yaitu siklus I dan siklus II. Tiap siklus terdiri atas perencanaan, tindakan, observasi, dan refleksi. Sebelum memasuki kedua siklus dilakukan prasiklus, hal ini dilakukan untuk mengetahui kondisi awal keterampilan siswa dalam menulis teks berita. Subjek penelitian ini adalah keterampilan menulis menulis teks berita pada kelas VIII B SMP Negeri 1 Keling Jepara. Berdasarkan analisis data penelitian keterampilan menulis teks berita siswa dari prasiklus, siklus I, sampai siklus II mengalami peningkatan. Sebelum dilakukan tindakan, nilai rata-rata klasikal menulis berita siswa sebesar 63,36. Selanjutnya pada siklus I meningkat menjadi 72 . Pada sikus II meningkat lagi menjadi 79,08. Hal ini menunjukkan bahwa terjadi peningkatan sebesar 15,72 dari pratindakan sampai siklus II. Peningkatan keterampilan menulis teks berita ini diikuti dengan perubahan perilaku siswa kelas VIII B SMP Negeri 1 Keling Jepara dari negatif kearah positif. Pada siklus II siswa terlihat lebih antusias mengikuti pembelajaran dan lebih tertarik terhadap pola pembelajaran yang diterapkan guru. Selain itu, siswa juga terlihat lebih aktif dan bersemangat dalam mengikuti pembelajaran. Situasi kelas pun lebih kondusif sehingga proses pembelajaran dapat berjalan dengan lancar. Melihat hal tersebut dapat disimpulkan bahwa penggunaan model pembelajaran quantum teaching dan teknik $3 \mathrm{M}$ dapat meningkatkan keterampilan menulis teks berita siswa dan perubahan perilaku siswa ke arah positif (Amalia, 2010).

Hasil Penelitian relevan kedua adalah penelitian yang ditulis Tri Indriaty dengan judul "Peningkatan Kemampuan Menulis Teks Berita Melalui Metode Quantum Learning dengan Media Gambar Siswa Kelas VIIIE SMP Negeri 17 Surabaya". Pelaksanaan dalam penelitian ini akan dilakukan dalam tiga siklus pengajaran atau pembelajaran. Dalam tiap-tiap siklusnya akan mengikuti tahap atau proses sebagai berikut: Perencanaan, implementasi, dan observasi, refleksi, dan revisi. Subjek penelitian ini ialah siswa kelas VIIIE SMP Negeri 17 Surabaya yang berjumlah 34 siswa, yang terdiri dari 16 laki-laki dan 18 siswa perempuan. Berdasarkan penelitian yang dilakukan selama tiga siklus, dapat diperoleh kesimpulan sebagai berikut: 1. Berdasarkan hasil pengamatan, aktivitas guru dalam pembelajaran menulis berita melalui pendekatan quantum learning dengan media gambar. Dapat disimpulkan bahwa kualitas aktivitas guru pelaksanaan pembelajaran tiap 
siklusnya mengalami peningkatan kualitas aktivitas guru didasarkan atas kemunculan persentase kemunculan aktivitas guru di tiap siklusnya. 2. Berdasarkan hasil pengamatan, aktivitas siswa dalam pembelajaran menulis teks berita melalui pendekatan quantum learning dengan media gambar menunjukkan peningkatan kualitas aktivitas siswa dalam tiap siklusnya. Peningkatan kualitas aktivitas siswa dalampembelajaran menulis teks berita didasarkan atas kemunculan persentase aktivitas siswa di tiap siklusnya. 3. Berdasarkan pencapaian hasil belajar siswa dalam pembelajaran menulis teks berita dengan media gambar dapat disimpulkan bahwa hasil belajar siswa dari tiap siklus pembelajaran menunjukkan peningkatan hal itu dapat diketahui dari perolehan nilai rata-rata siswa pada kondisi awal sampai pada pembelajaran siklus terakhir atau siklus ketiga menunjukkan peningkatan nilai rata-rata, dan keberhasilan belajar siswa itu dicapai pada pembelajaran siklus ketiga (Indriaty, 2018).

Berdasarkan dua riset relevan sebelumnya, penelitian kali ini lebih mendalam karena selain meneliti keterampilan menulis teks berita pada siswa, peneliti juga menganalisis setiap aspek dalam penulisan teks berita. Begitu pula pada variabel aktivitas siswa, meskipun dalam riset sebelumnya juga diteliti mengenai aktivitas siswa, namun dalam penelitian ini, setiap komponen aktivitas siswa juga dianalisis dan dibandingkan antar siklus.

Pembahasan hasil penelitian ini didasarkan pada tes siklus I dan siklus II. Pembahasan hasil tersebut meliputi hasil tes dan nontes. Pembahasan hasil tes penelitian mengacu pada pemerolehan nilai yang dicapai siswa ketika menulis teks berita. Aspek-aspek yang dinilai dalam pembelajaran menulis teks berita meliputi enam aspek, yaitu aspek kelengkapan unsur berita, keruntutan pemaparan, penggunaan kalimat, penggunaan kosakata, kemenarikan judul, dan ketepatan penggunaan ejaan Pembahasan hasil nontes meliputi observasi, jurnal, wawancara, dan dokumentasi foto.

a. Peningkatan keterampilan menulis teks berita

Perolehan hasil tes peningkatan keterampilan menulis teks berita pada siklus I dan siklus II siswa kelas VIII-6 MTs Negeri 5 Jakarta dapat dijelaskan bahwa ketuntasan dan hasil rata-rata nilai siswa untuk kompetensi menulis teks berita siswa dari siklus I sampai dengan siklus II mengalami peningkatan. Uraian tabel di atas, dapat dijelaskan secara rinci sebagai berikut. Pada tes prasiklus nilai rata-rata siswa sebesar 60,20 termasuk dalam kategori cukup (rentang nilai 60-69). Pada siklus I nilai rata-rata siswa sebesar 66,94 atau dalam kategori cukup (rentang nilai 6069) sedangkan pada siklus II hasil tes menjadi 78,79 dalam kategori baik (rentang nilai 70-84). Peningkatan dari prasiklus ke siklus I sebesar 6,74. Pada siklus II mengalami peningkatan sebesar 11,85 dari hasil siklus I. Setelah pelaksanaan tes menulis teks berita pada prasiklus dan siklus I dengan nilai rata-rata 60,20 dan 66,94 atau dalam kategori cukup. Prasiklus dan siklus 133 masih belum mencapai nilai ratarata batas minimal, yaitu 75 , sehingga hasil tersebut perlu ditingkatkan lagi pada siklus II. 
Pada aspek kelengkapan unsurunsur teks berita, pada prasiklus siswa mencapai nilai rata-rata sebesar 22,32 pada siklus I mencapai nilai rata-rata sebesar 24,35 sedangkan pada siklus II sebesar 27,18. Pada aspek kelengkapan berita siswa sudah mampu menjabarkan unsur-unsurnya dalam bentuk teks berita. Pada tahap siklus I, siswa hanya menyebutkan tiga sampai lima unsur berita. Untuk mengatasi kekurangan ini maka siswa diminta berlatih menulis teks berita dengan dibimbing oleh guru sehingga pada siklus II, sebanyak 27 siswa mampu menuliskan enam unsur berita. Nilai rata-rata siswa masuk dalam kategori baik.

Pada aspek keruntutan
pemaparan, nilai rata-rata pada
prasiklus 12,23, siklus sebesar $13,17$.
prasiklus 12,23, siklus I sebesar 13,17. Pada siklus II terjadi peningkatan sebesar 15,29. Berdasarkan hasil tersebut menunjukkan telah terjadi peningkatan sebesar 2,12. Pada siklus I ketika siswa menulis teks berita tidak memperhatikan keruntutan pemaparan sedangkan pada siklus II siswa sudah mampu menulis teks berita dengan menulis informasi yang lebih penting terlebih dahulu lalu diikuti dengan informasi yang sifatnya kurang penting.

Pada aspek penggunaan kalimat untuk prasiklus mencapai nilai 6,97 siklus I mencapai nilai rata-rata sebesar 7,58 sedangkan pada siklus II mencapai nilai rata-rata hingga 10,68 . Hal ini menunjukkan pada siklus II siswa sudah mampu menulis teks berita dengan menggunakan kalimat efektif. Pada aspek penggunaan kosakata, nilai ratarata pada prasiklus 7,15 siklus I sebesar 8,65 sedangkan pada siklus II terjadi peningkatan nilai rata-rata mencapai 10,85 . Hal ini menunjukkan pada siklus
II siswa sudah mampu menulis teks berita dengan menggunakan kosakata yang tepat.

Pada aspek pemilihan judul, nilai rata-rata pada prasiklus 7,82 , siklus I sebesar 7,98 dan pada siklus II nilai rata-rata mencapai 8,29. Siswa sudah mampu dalam menentukan judul teks berita yang akan mereka tulis sehingga pada hasil tes pada siklus II mengalami peningkatan. Hal ini menunjukkan siswa tidak mengalami kesulitan dalam menentukan judul teks berita. Pada aspek ketepatan penggunaan ejaan, pada prasiklus mencapai nilai 4,34, siklus I mencapai nilai rata-rata sebesar lima sedangkan pada siklus II mencapai nilai rata-rata sebesar 6,76. Sebagian besar siswa mengalami kesulitan dalam penggunaan ejaan bahasa Indonesia yang disempurnakan. Peneliti menemukan banyak kesalahan ejaan yang terdapat dalam hasil menulis teks berita. Kesalahan-kesalahan terdapat dalam penulisan huruf kapital, pemakaian tanda baca yang kurang tepat, dan penulisan kata yang disingkat.

Dalam penelitian ini aspek yang paling banyak dicapai siswa yaitu pada aspek kelengkapan unsur berita dan pemilihan judul. Pada kedua aspek ini jumlah skor siswa dapat dikatakan baik. Dari hasil pembahasan di atas dapat diketahui bahwa terjadi peningkatan keterampilan menulis teks berita siswa kelas VIII-VI MTs Negeri 5 Jakarta setelah dilakukan pembelajaran kuantum.

b. Peningkatan aktivitas belajar

Selama proses pembelajaran kuantum dilakukan pengamatan terhadap perilaku siswa. Pengamatan dilakukan mulai siklus I sampai siklus II 
berakhir. Proses pengamatan dilakukan melalui instrumen nontes yang berupa observasi, jurnal, wawancara, dan dokumentasi foto. Berikut ini pemaparannya.

\section{1) Hasil Observasi}

Perbandingan hasil observasi siklus I dan siklus II pada aspek pertama yaitu kesiapan siswa dalam mengikuti pembelajaran mengalami peningkatan sebesar $38,24 \%$, siklus I sebesar $61,76 \%$ dan siklus II sebesar 100\%. Pada siklus I masih terdapat siswa yang tidak bersungguh-sungguh dalam mengikuti pembelajaran dan sebagian siswa masih bergurau dengan temannya. Pada siklus II kondisi kelas lebih tenang, siswa bersungguh-sungguh dalam mengikuti pembelajaran.

Aspek yang kedua yaitu siswa memperhatikan penjelasan yang disampaikan oleh guru mengalami peningkatan sebesar 35,29\%, siklus I sebesar 52,94\% dan siklus II sebesar $88,23 \%$. Pada siklus I, terdapat sebagian siswa yang tidak memperhatikan penjelasan guru. Siswa masih meremehkan penjelasan yang disampaikan oleh guru. Pada siklus II siswa memperhatikan dan bersungguhsungguh ketika mendengarkan penjelasan dari guru.

Aspek yang ketiga yaitu siswa senang dan tertarik dengan media $f$ yang dihadirkan oleh guru mengalami peningkatan sebesar 17,65\%, pada siklus I sebesar $76,47 \%$ dan siklus II sebesar 94,12\%. Pada siklus I terdapat 26 siswa yang senang dan tertarik dengan media yang disajikan oleh guru sedangkan pada siklus II terdapat 32 siswa yang senang dan tertarik dengan media yang disajikan oleh guru. Siswa memperhatikan media dengan cermat.
Aspek yang keempat yaitu siswa bersungguh-sungguh dalam menulis teks berita mengalami peningkatan sebesar 38,23\%, pada siklus I sebesar 47,06\% dan siklus II sebesar 85,29\%. Pada siklus I masih terdapat siswa yang tidak bersungguh-sungguh dalam menulis teks berita. Siswa tidak memanfaatkan waktu seefektif mungkin dalam menulis teks berita. Pada siklus II siswa bersungguh-sungguh ketika menulis teks berita. Siswa menulis teks berita sesuai dengan informasi yang diberikan.

Aspek yang kelima yaitu siswa aktif bertanya kepada teman maupun guru apabila menemukan kesulitan, mengalami peningkatan sebesar $26,47 \%$, pada siklus I sebesar $32,35 \%$ dan pada siklus II sebesar $58,82 \%$. Pada siklus I, siswa masih mengalami kesulitan dalam menulis teks berita tetapi mereka tidak aktif bertanya kepada guru mengenai kesulitan yang dihadapi. Pada siklus II, siswa sudah tidak merasa malu ketika bertanya kepada guru. Hal ini disebabkan siswa ingin menulis teks berita dengan baik.

Aspek yang terakhir yaitu siswa tidak mengganggu temannya mengalami peningkatan sebesar $14,71 \%$, pada siklus I sebesar $79,41 \%$ dan siklus II sebesar 94,12\%. Pada siklus I, masih terdapat siswa yang suka mengganggu temannya. Beberapa siswa masih berbicara dengan temannya sedangkan pada siklus II siswa sudah mampu berkonsentrasi ketika diminta menulis teks berita sehingga mereka tidak mengganggu temannya.

2) Hasil Jurnal

Pada aspek yang pertama yaitu, pendapat siswa tentang pembelajaran 
kuantum. Jumlah siswa yang senang dan tertarik terhadap pembelajaran menulis teks berita pada siklus II lebih banyak daripada siklus I. Siswa menyukai pembelajaran kuantum karena dapat mempermudah menulis teks berita.

Pada aspek yang kedua yaitu, kesulitan yang dialami siswa dalam menulis teks berita. Pada siklus I siswa banyak yang merasa kesulitan dalam menyusun kalimat dan menggunakan ejaan yang tepat. Pada siklus II siswa sudah memahami materi yang disampaikan oleh guru karena materi tersebut telah disampaikan pada pertemuan sebelumnya.

Pada aspek yang ketiga yaitu, tanggapan siswa terhadap gaya mengajar guru saat memberikan penjelasan. Pada siklus I siswa merasa penjelasan yang diberikan guru terlalu cepat sedangkan pada siklus II siswa merasa penjelasan guru sudah bisa dipahami karena guru menjelaskan materi lebih detail dan tidak terlalu cepat.

Pada aspek yang keempat yaitu manfaat yang diperoleh siswa setelah mengikuti pembelajaran kuantum. Siswa menyatakan dengan adanya pembelajaran kuantum dapat mempermudah menulis teks berita pada siklus I dan Aspek yang terakhir yaitu, siswa memberikan pesan, kesan, dan saran terhadap penggunaan pembelajaran kuantum dalam pembelajaran menulis teks berita. Pada siklus I maupun siklus II keseluruhan siswa memberikan pesan, kesan, dan saran. Siswa menginginkan pembelajaran yang menyenangkan diterapkan terhadap mata pelajaran yang lain.
Kesiapan siswa dalam mengikuti pembelajaran lebih baik pada siklus II daripada siklus I. Hal ini terlihat ketika pembelajaran siklus I akan dimulai, masih banyak siswa yang belum siap dan berbicara dengan temannya. Pada siklus II, saat mengikuti pembelajaran siswa tidak berbicara dengan siswa yang lain sehingga suasana tercipta suasana kondusif dalam proses pembelajaran. Siswa lebih tenang dalam mengikuti pembelajaran.

Keaktifan siswa dalam mengikuti pembelajaran menulis teks berita siklus II lebih baik daripada siklus I. Hal tersebut terlihat dari banyak siswa yang aktif bertanya ketika mengalami kesulitan. Jumlah siswa yang bertanya mengalami peningkatan karena siswa ingin menulis teks berita dengan benar.

Pada siklus I banyak siswa yang masih mengeluh ketika diminta untuk menulis teks berita sedangkan pada siklus II siswa menulis teks berita dengan serius dan sungguh-sungguh. Siswa memanfaatkan waktu seefektif mungkin untuk menulis teks berita.

Tanggapan siswa terhadap pembelajaran kuantum ditunjukkan dengan siswa merespon secara baik ketika guru menyajikan pembelajaran. Menurut siswa, pembelajaran kuantum dapat memudahkan menulis teks berita.

Suasana kelas ketika pembelajaran menulis teks berita siklus II lebih kondusif dibanding dengan sebelumnya. Hal ini karena siswa lebih merasa termotivasi dan tertarik dengan pembelajaran yang diberikan.

3) Hasil Wawancara

Wawancara difokuskan pada siswa yang mendapat nilai tertinggi, nilai sedang, dan nilai terendah. 
Kegiatan wawancara ini bertujuan untuk mengetahui tanggapan yang diberikan siswa dalam pembelajaran kuantum. Dari hasil wawancara pada siklus I dan II dapat disimpulkan bahwa terjadi perubahan perilaku ke arah positif. Pada wawancara siklus I dan siklus II, siswa menyatakan bahwa mereka menyukai pembelajaran yang telah dilakukan. Pembelajaran menyenangkan dan tidak membosankan. Semula pada siklus I banyak yang mengalami kesulitan dalam menyusun kalimat dan menggunakan ejaan yang tepat. Pada siklus II para siswa mengatakan bahwa tingkat kesulitannya menjadi berkurang karena bertambahnya pemahaman mengenai aspek penggunaan kalimat dan ketepatan ejaan. Selain dari kegiatan wawancara terbukti dari hasil pengamatan observasi, minat siswa dalam mempelajari teks berita juga lebih tinggi dari siklus I.

\section{PENUTUP}

\section{Simpulan}

Keterampilan menulis teks berita siswa kelas VIII-6 MTs Negeri 5 Jakarta tahun ajaran 2019/2020 setelah mengikuti pembelajaran kuantum mengalami peningkatan. Pada prasiklus diperoleh nilai rata-rata sebesar 60,20 termasuk dalam kategori cukup. Hasil siklus I diperoleh nilai rata-rata kelas sebesar 66,94 termasuk dalam kategori cukup. Pada siklus II, diperoleh nilai rata-rata kelas sebesar 78,79 termasuk dalam kategori baik. Dengan demikian, terjadi peningkatan nilai rata-rata dari siklus I ke siklus II sebesar $11,85 \%$. Hal ini menunjukkan bahwa setelah dilakukan penelitian menulis teks berita melalui pembelajaran kuantum, kemampuan siswa menulis teks berita meningkat.

Aktivitas belajar siswa kelas VIII-6 MTs Negeri 5 Jakarta tahun ajaran 2019/2020 setelah mengikuti pembelajaran kuantum mengalami perubahan ke arah yang positif. Hal tersebut dapat diketahui dari hasil nontes meliputi hasil observasi, jurnal, wawancara, dan dokumentasi foto pada siklus I dan siklus II. Berdasarkan analisis data hasil nontes pada siklus I, masih terdapat siswa yang berperilaku negatif selama melaksanakan pembelajaran. Sebagian besar siswa belum siap ketika mengikuti pembelajaran, belum aktif atau masih merasa malu bertanya kepada guru mengenai kesulitan yang dihadapi, dan masih terdapat siswa yang tidak memperhatikan penjelasan dari guru. Namun, pada siklus II siswa telah mengalami perubahan ke arah yang lebih positif. Hal tersebut terlihat dari sikap siswa yang antusias, lebih tertarik, dan bersemangat dalam mengikuti kegiatan pembelajaran. Sebagian besar siswa lebih aktif selama pembelajaran. Siswa juga lebih siap menerima pelajaran dan lebih berfokus memperhatikan penjelasan guru. Menyajikan ringkasan dari uraian mengenai hasil dan pembahasan, mengacu pada tujuan penelitian. Berdasarkan hasil penelitian ini dan riset relevan sebelumnya, pembelajaran kuantum tidak hanya meningkatkan keterampilan menulis teks berita siswa secara rata-rata keseluruhan, namun juga meningkatkan setiap aspek penulisan berita dimana juga dapat diterapkan dalam menulis teks selain teks berita. 


\section{Rekomendasi}

Bagi guru mata pelajaran bahasa dan sastra Indonesia hendaknya menggunakan pembelajaran kuantum sebagai metode pembelajaran. Pembelajaran kuantum terbukti dapat meningkatkan keterampilan siswa dalam menulis teks berita. Selain itu, pembelajaran kuantum dapat membuat proses pembelajaran menjadi lebih menarik dan menyenangkan.

Bagi siswa hendaknya terus mengingat dan mengulangi proses pembelajaran kuantum untuk belajar secara mendiri. Pembelajaran kuantum dapat digunakan sebagai metode pembelajaran menulis karena memiliki keunggulan yaitu dapat merangsang daya pikir dan imajinasi siswa serta memberikan pengalaman yang menyenangkan bagi siswa.

Para peneliti lain yang menekuni bidang penelitian bahasa dan sastra Indonesia hendaknya dapat melakukan penelitian lanjutan mengenai keterampilan menulis teks berita.

\section{DAFTAR PUSTAKA}

Amalia, R. F. (2010). Peningkatan Keterampilan menulis Teks Berita Menggunakan Model Pembelajaran Quantum Teaching dan Teknik 3M pada Siswa Kelas VIII B SMP Negeri 1 Keling Jepara. Skripsi, Universitas Negeri Semarang, Fakultas Bahasa dan Seni, Jurusan Pendidikan Bahasa dan Sastra Indonesia. Diambil kembali dari https://lib.unnes.ac.id/9039/1/11484a.pdf

DePorter, B., \& Hernacki, M. (2015). Quantum Learning: Membiasakan Belajar Nyaman dan Menyenangkan. (A. Abdurrahman, Penerj.) Bandung: Kaifa.

Djuraid, H. (2009). Panduan Menulis Berita. Malang: UPT Penerbitan Universitas Muhammadiyah Malang.

Hamalic, O. (2009). Kurikulum dan Pembelajaran. Jakarta: Bumi Aksara.

Indriaty, T. (2018). Peningkatan Kemampuan Menulis Teks Berita Melalui Metode Quantum Learning dengan Media Gambar Siswa Kelas VIII-E SMP Negeri 17 Surabaya. Jurnal Kajian Bahasa, Sastra dan Pengajaran (KIBASP), 223-236. doi:https://doi.org/10.31539/kibasp.v1i2.195

Suryadi, A., \& Berdiati, I. (2018). Menggagas Penelitian Tindakan Kelas bagi Guru. Jakarta: Remaja Rosdakarya.

Wena, M. (2013). Strategi Pembelajaran Inovatif Kontemporer: Suatu Tinjauan Konseptual Operasional. Jakarta: PT Bumi Aksara. 